\title{
¿Qué cuerpos importan? Reflexiones sobre (des)hacer un canon escolar sexista
}

\author{
Pamela Bórtoli ${ }^{(1)}$
}

Palabras clave. literatura · género . manuales · canon

Resumen. El presente trabajo se desprende de una investigación en curso que tiene como objetivo profundizar y ampliar el conocimiento del género (gender) en manuales utilizados para la enseñanza de literatura en Argentina, durante ciertos momentos históricos de inflexión: 1984, 1995, 2006. En esta oportunidad se evidencia cómo la noción de «manual de literatura» (Bórtoli, 2012) se cruza con la de mercado, y permite realizar investigaciones históricas que habilitan la posibilidad de examinar la vida escolar cotidiana y las representaciones que se crean acerca de ella (Carbone, 2012). En este sentido, y haciendo principal hincapié en el estudio de las representaciones de género, se presenta un análisis del canon que circula en las propuestas editoriales de Santillana.
Keywords. literature gender . textbooks $\cdot$ canon

Abstract. This paper emerges from a present investigation that aims to deepen and broaden the knowledge of gender in textbooks used for the teaching of literature in Argentina, during certain historical moments of inflection: 1984, 1995, 2006. This time it tries to demonstrate how the notion of «manual de literatura» (Bórtoli, 2012) intersects the market, and allows to do historical researches that enables the possibility of examining the everyday school life and representations that are created about it (Carbone, 2012). In this sense, and emphasizing the study of gender we present an analysis of school canon proposals circulating in Santillana.

(1) Facultad de Humanidades

y Ciencias, Universidad Nacional

del Litoral. CONICET

E-mail: bortoli_p@hotmail.com 